\title{
EGYPTOLOGY AND TOUR GUIDING, BRIDGING THE GAP BETWEEN THEORY AND PRACTICE "APPLIED STUDY TO SELECTED SITES IN LUXOR"
}

\section{HAITHAM T. SOTOHY}

THE HIGHER INSTITUTE OF TOURISM AND HOTELS (EGOTH), LUXOR, EGYPT

\begin{abstract}
This paper studies the link between the career of tour guiding and the knowledge the guide must possess. Tour guiding in archeological sites Egypt is connected to the knowledge of Egyptology; a skill the guide must show while working in those areas. Luxor as the most important touristic city in Egypt, and also the most important city in ancient Egyptian history; the city was selected as the sample of the study, where selected places are linked with Egyptological studies to reveal its importance, and how those sites could be guided through using the academic tools such as ancient Egyptian language, and how such knowledge could add to the tour guiding in those sites.
\end{abstract}

KEYWORDS: TOUR Guiding, Egypt, Egyptology, Archeological sites, Luxor, Karnak temple, Luxor temple, West bank.

\section{INTRODUCTION, TOUR GUIDING AND CULTURAL TOURISM}

The cultural tourism was considered by the United Nations World Tourism Organization (UNWTO), one of the major growth markets in global tourism (UNWTO, 2001). According to this organization the cultural tourism represents between $35-40 \%$ of all tourism worldwide, and this type of tourism is growing at around $15 \%$ per annum, nearly three times of growth of tourism in general (Van der Merwe, 2016, 118). Tour guiding, is one of the oldest professions in tourism industry, through its relation to cultural tourism, it has a critical importance in terms of promoting the natural and historical wealth of a country effectively and efficiently (İrigüler and Güler 2016, 203)

Tour guiding plays a very important role in tourism industry, because tour guides are the closest persons to the tourist all over the whole tour (AL Rawadieh 2015, 10). Tour guides are the main role-players within the cultural tourism and their perceptions of heritage tourism represents an important factor for enhancing the whole industry (Van der Merwe, 2016, 118). The success of the tourism industry depends in great extent on the performance of tour guides in each destination. Tour guides are the front- 
line staff who provide the "moment of truth" for tourists and can achieve or break their trip (Zhang and Chow 2004).

Scholars differentiate between two kinds of tour guides; pathfinder; a classical guide who just lead the tour, and mentor or innovative guide; a culture broker who change the tour to a special tutorial experience (Cohen $1985,8)$. Academics have noted that there is a need for making a shift in tour guiding communication from presenter/ entertainer to an experience focus, and as orchestrating or choreographing the experience (Weiler and Black 2015b, 365).

Professional tour guiding is a work with high professional return and satisfaction. Tourists believe that successful guides have extensive knowledge on the history and culture of visiting places (Yenipinar 2016, 73)

A good guide considers himself a professional, and invests in his development. The guides must keep learning, to remain relevant in a dynamically changing world, where new audiences are emerging and visitors increasingly feel the need for personal connection. Tour guides need a shift in their career to be more highly skilled experience-brokers, using information to choreograph memorable experiences (Weiler and Black 2015b, 364).

The communicative role of the guide must be re-evaluated, and the guided tours in general must be presented in a different way. In this context the traditional one-way communication appears too poor in a consumer centered tourism industry. There a need for a shift in tour guiding communication on the side of the tour guide; as orchestrating or choreographing the experience, and for the tour group members to be viewed as active participants (Weiler and Black 2015b, 364).

\section{GUIDING IN ARCHEOLOGICAL SITES}

Many scholars studied the role and performance of tour guides, but on contrary; there are very little studies dealing with analysis of guides' interpretation in archaeological context. A significant amount of tourismrelated literature focused on the role and functions of tour guides, others dealt with the performance and service quality. Few studies tried to empirically investigate the guides' interpretation at heritage sites. There is shortage in the knowledge about tour guides, interpretation, and there is a gap in research on different interpretation techniques. Only limited attention has been given to the academic knowledge and personal interpretation of tour guide in heritage sites, this increased the demand for 
a more thorough understanding of guides' interpretation in archeological sites (Ababneh 2018, 161).

In Egypt; guiding in archeological sites is not an easy task; the knowledge of Egyptology is the cornerstone in guiding career. The tour guides in Egypt receive a special education focuses on history and Archeology and other Egyptological branches related to the ancient sites they are working in. Special academic qualities are essential in professional guiding in ancient Egyptian archeological sites.

Many authors acknowledge the multiple roles of the guide and note that the relevant, skills and knowledge to perform these roles can be addressed through training and education (Black 2002; Black and Weiler 2005).

The Archeological sites as attractions could be transformed by a professional guide into authentic ones. The suitable interpretation by the guide contribute to gradual "sacralization" of those sites, by putting them into their proper historical and religious atmosphere through interpretative "keying" of the tourist's perceptions (MacCannell 1976:44 - 45,Cohen 1985,26; Cohen 1972, 170- 171).

\section{EGYPTOLOGY AND TOUR GUIDING}

The majority and the most outstanding of the archeological sites in Egypt date back to the ancient Egyptian history. The knowledge of Egyptology is essential in delivering a good interpretation in archeological sites in Egypt. The academic and right information distinguished the professional guide in Egypt. The next part of this research discussing the relationship between some issues in Egyptology; how it could affect the improvement of tour guiding in archeological sites in Luxor.

\section{THE ROLE OF ANCIENT EgYPTIAN LANGUAGE IN TOUR GUIDING}

The knowledge of Ancient Egyptian language is a very important skill in tour guiding in Egyptian archeological sites. Reading the texts is not enough, but selecting important one is a very elementary factor in guid ing in an archeological site. It was noted that selection for the guide is a very important skill; he must be trained to select the most important objects of interest during his tour (Cohen 1985, 14). This will transform the guide from pathfinder or original guide to professional guide or mediator; the one who provide information and interpretations of the site visited (Nettekoven 1979, 142; Cohen 1985, 20). In archeological sites because there are a lot of scenes and texts, the tour guide or his tutor - through professional training - his role is to point out the most important of those scenes or texts.

In Luxor temple an example of selecting an important text to reinforce the guiding process is to be mentioned here. For Egyptologists Luxor temple is 
a question; with a second temple -Karnak temple- in the north of Luxor we must ask why; why the same kings in the same city for the same god built a second temple.

Many Egyptologists tried to answer this question; in his study of the temple Lanny Bell (Bell 1998) shows that Luxor temple has a different function than Karnak, and it is related to the worship of the royal $k a$ (soul). The evidence for this theory is the two seated statues in the first court; the text on the base of the western seated statue at the southern end of the court speaks about this special function of the temple, it reads:

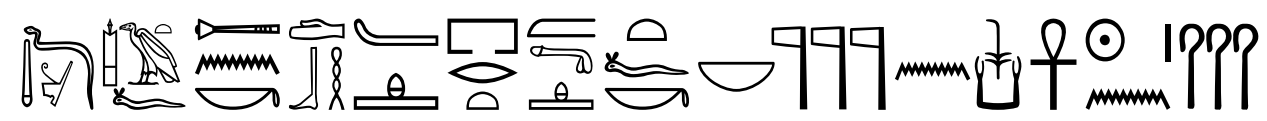

dd mdw in'Iwn-mwt.fm n.kdbh htp pri. tw m-b3h it.knbntrw n k3-nsw `nh $r^{\mathrm{c}}-n-$ $h k 3 w$

A recitation by Inmutef, take to yourself, offering meal, presented in front of your father, lord of the gods, to the living royal ka, Sun of the rulers (Sotohy 2016, 54)

This text is the main evidence that the function of Luxor temple is the worship of the royal ka, so it is a must for the professional tour guide to make use of it. This text is the main key to understand the function of those two statues of the deified king, and in this context Luxor temple is functioning as a royal shrine stressing the importance of the king. Depending on theses information the guide in Luxor temple; their job is to maintain and strengthen the attractiveness of the place.

\section{EGYPTOLOGICAL IDEAS ABOUT SELECTED SITES IN LUXOR, AND HOW THEY AFFECT GUIDING}

Regarding guiding interpretation in this academic way, the guide will make use of all the Egyptological knowledge to show the site in right, academic, and professional way. In some sites in Luxor the Egyptological knowled ge changes the general - or classical - view of the place, to be presented in another right way, using a different approach in dealing with scenes, texts, or architectural features. Here are some examples of how Egyptological knowledge changes the view in some places, for the benefit of the guide.

\section{KARNAK}

An example of the sacred lake of Karnak is to be mentioned here. The sacred lake of Karnak is of special importance in the religious practices of the temple. In the sacred lake area the story of creation was re-enacted, the 
priests showing for the people the Sun-god appeared again on the waves of the primeval ocean Nun which is now the waters of the sacred lake (Weeks 2005: 101-102, Shaw and Nicholson 2002: 249)

It is here that the guide must link the lake to its ancient function, and refers to the relation of the lake to the scarab beside it; of course this is a new and more logic theory about the lake and not to link it with purification, which is a wrong interpretation. Many academics mention that three thousand years ago temple priests avoided the lake (Weeks 2005: 101-102), not because it was polluted, but because religious regulations demanded that they use fresh, flowing water for their daily ablutions. The priests did row small sacred barks across the lakes surface on festival days to re-enact the myth of the lake front of the viewers in festival days.

\section{TEMPLES OF MILLIONS OF YEARS}

The site of western Thebes is regarded as one of the most important archeological sites all over the world; it was one of the first sites listed by UNESCO as a World Heritage site in 1979 (UNESCO; Strudwick and Strudwick 1999, 7; Weeks 2001:22). Many temples mark western Theban topography. Interpreting such a temple in the necropolis of western Thebes is very important issues which the guide must deal with; because these temples are architecturally similar to the other temples of eastern Thebes, so the guide must differentiate between the two types of temples through their interpretation in order to put western Theban temples in their proper archeological context.

Western Thebes temples were designated as "mortuary temples", but The ancient Egyptians had no word for the concept "mortuary temple", Yet scholars have accepted the meaning of this modem term and they have felt no need to define it accurately, they were defined as "a royal temple in the Theban necropolis, near the royal tombs ". But in fact, the ancient Egyptians' attitudes toward life and death were different from modern ones (Haeny 1998: 123). An expression that is frequent in texts referring to temples of the western Theban necropolis temples is "Temples of Millions of Years" (Haeny 1998: 124).

The purpose of royal "Temples of Millions of Years" was not solely that of a funerary temple. That function, supplied by priests appointed to serve the ruler's cult, both during and after his lifetime on earth, was combined with several others. The theology of the New Kingdom, as interpreted for the ruler's cult, would guarantee the king's eternal deification and identification with the sun god and with Osiris. The temple shared the work of the tombs in the Valley of the Kings where the texts guaranteeing the king's rebirth with the solar gods were amplified. While the foreparts 
of the temples celebrated the king's close association with Amen- Ra, in the deepest sanctuaries the king's identification with $\mathrm{Ra}$ and Osiris was stressed to guarantee his dominion over the heavens and the netherworld (Bryan 2001: 56).

Temples of millions of years were of great importance for the king more than just a role in funerary practices. These temples unite kingship with mortuary practices, they also played a very important role in the Beautiful Festival of the Valley, which is a reference to the union between living and dead, between kings and gods. Beside the chapels for the deified king; these temples contained chapels for gods; namely Amen and the solar cult. These temples had a very important role in the economy of the State (Weeks 2005: 144-145).

\section{Medinet Habu Temple}

The special function of the temples of millions of years could be attested in Medinet Habu temple for the king Ramesses III. According to this view the temple can be understood through dividing it into three main areas: the first court, which is the most public part of the temple, while the most important feature in this court is the "window of appearances" from which the king appears for the public audiences; the second court, with relieves showing the celebration of the annual feasts of the underworld gods, Min and Sokar; and the main temple beyond, a place where those gods reside or "lived"(Murnane 1999: 581).

The interpretation of the temple must depend on the understanding of the basic elements in the temple plan and it is the decorative program that is the best guide to the way in which the temple functioned in ancient times. Because this is a temple commemorates the defied king, two aspects of the king are represented within. On the south side, many elements are associated with the king's mortality and his deification in the underworld; these themes are evoked by the palace and the "window of appearance" from which the deified king appears (first court) and the festival of underworld gods, namely Sokar, a divinity who resides in the underworld (second court). The king's divine personality and his identity are represented on the north side of the building, that is shown in the colossal royal statues of the northern portico in the first court, and in the festival scenes in the second court of god Min, which represent a fertility god who (re)creates himself and thus represent the eternal cycle of nature (Murnane 1999: 581)

The progress of the scenes in the temple is parallel to the progress of the divine personality of the king now joined the gods as one of them. As the visitor passes out of the Osiris complex, the figure of the resurrected king 
is virtually the last encountered: in Room 20, on the west wall, we see him inside a portable shrine, facing out towards the hypostyle. The text front of him reads:

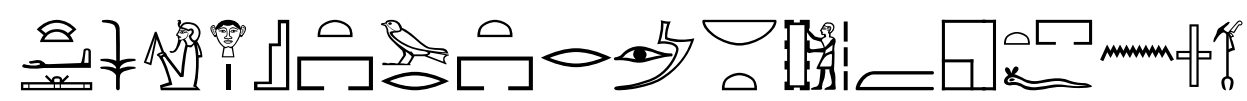

$h^{\complement}$ nsw hrr st wrt $r$ m33 nbt kdw m ḥwt.fn imy w3st

The king arise in the shrine to see all works (buildings) in his temple which is in Thebes. The accompanying litany ensures that the name (= essence) of the king and his mortuary temple will last for the length of eternity:

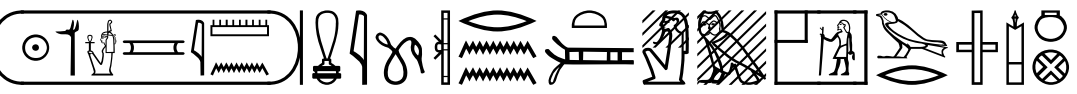

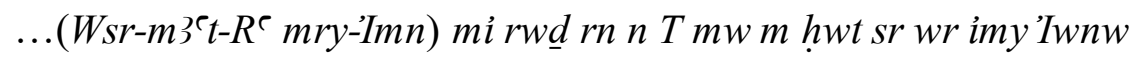

...May the name of the King of Upper and Lower Egypt, Ramesses III flourish

As the name of Atum flourishes in the Mansion of the Prince (law court) who is in Heliopolis.

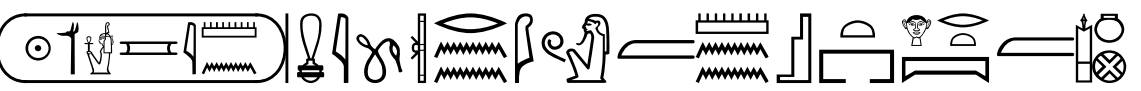

...(wsr-m3`t-R` mry-Imn) mi rwd $r n n$ Šw m mnst hrt m 'Iwnw

...As the name of Shu flourishes in Upper Menset, in Heliopolis...

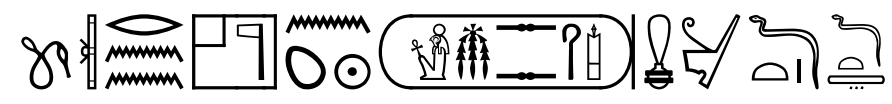

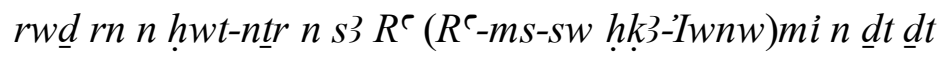

May the name of the Temple of the Son of Re, Ramesses III, flourish likewise for ever and ever (Sotohy 2016, 165).

Here in this scene the king is represented re-created again and appears as a god joined the underworld gods in the necropolis. This state is achieved through scenes and texts of the temple. This is the scientific interpretation of an example of the western Theban necropolis temples depending on the knowledge of Egyptology. An interpretation of the guide must depend on these academic theories to put the monument in its proper historical and religious context.

\section{TOMBS OF THE NOBLES}


The fourth example of how the knowledge of Egyptology could enhance the tour guide performance in an archeological site in Luxor is the interpretation of the scenes of the tombs of the nobles in western Thebes.

These tombs which were dedicated for the high officials in the Theban necropolis are known as the "Tombs of the Nobles". They are the burial places of the most important personalities of the city during the new kingdom period. Those are governors, high priests, administrators and their like. But those tombs were regarded as the place where the spirits of those people would live after death and also served as a place for their cult, where offerings would be presented and rituals carried out for the benefit of the tomb owners. The tomb for the ancient Egyptian helped to perpetuate the memory its owner, and later it also became a cult place for certain deities favored by or close to the deceased (Strudwick and Strudwick 1999: 139).

\section{DECORATION}

\section{THE PURPOSE OF THE TOMB DECORATION AND ITS MEANING}

The decoration of each tomb could be explained as the way by which the tomb owner ensures the continued existence of all the things depicted on the walls. It is noted that the front (offering) chapels of each tomb is the place where the rites for the tomb owners are depicted, of course the most important among those rites was the regular supply of food and drink for the spirit of the deceased. This supply of offerings depicted on walls could replace the supply of food which is attested in documents show the agreement which were made between the tomb owner during his life and his relatives or priests who would look after his tomb and provide offerings for his spirit (Strudwick and Strudwick 1999: 153).

Another deep understanding of the ordinary daily life scenes in the private tomb was supposed by Egyptologists. The fishing and fowling scenes in nobles' tombs were re-considered by some academics, an explanation which would enhance the interpretation of those scenes by the tour guide.

\section{THE FISHING AND FOWLING SCENE SYMBOLISM}

Fishing scenes is a recurrent theme in private tombs in Thebes, a new explanation of those scenes was suggested by academics in more than one place. The theories simply refer to those scenes in religious and mortuary context; so another interpretation is to be presented for those scenes to reinforce the understanding of their role for the tomb owner. This is a very important point where the guide can make use of Egyptology knowledge to reinforce his interpretation for the nobles' tombs. 
In fishing and fowling scenes there is a visual play of words symbolising the rebirth. The visual pun of throwing a stick in the scene is to be equated with its hieroglyphic sign in the word $\mathrm{km} 3$ "to create" and "to beget". Another word for spearing a fish, sti, resembles the spelling of the word "impregnate" (Hartwig 2004, 105-106).

The key to a proper understanding of the fishing scenes lies in the symbolism of the two fishes which are put in the center of each scene, with the harpoon pointing straight at them so artist here want the seer to focus on them. The fish in the scenes is tilapia a fish with a curious habit of swallowing its young fishes when in danger, but spit out them unharmed once the danger is over. This habit drew the attention of the ancient Egyptians, they considered the little ones had died, but had been strangely reborn. This met their own hopes of being reborn after death, and the tilapia thus became a symbol of rebirth and was connected to Hathor, the goddess represented fertility and rebirth, because of this mouth-brooding habits. Also it was connected with the Creator God Atum, who took his seed in his mouth and spat out the world. Also the brilliant red colour of the tilapia led to its name "red fish" and connected it with the sun as the guardian and protector of the solar boat on its daily cycle. The Book of Dead showed the deceased's wish to "see the Tilapia (int) in the stream of turquoise" when sailing with the sun god in his sacred bark (Hartwig 2004: 105; Manniche 1987: 35-36).

The second fish represented in the scene is the Lates or Nile Perch a fish which was connected to rebirth, and was a symbol for the goddess Neith, who turned herself into a Lates to could navigate the primeval waters of Nun. The whole scene is centered on this idea. Fowling was an element into the whole scene presenting another aspect of the idea of rebirth. Osiris himself, the ideal example of deceased in ancient Egypt; departed from the world of the living, then had speech and movement restored to him, and most specifically his ability to go fowling (Hartwig 2004: 105).

By spearing the Lates and Tilapia fish in the Fishing and Fowling scenes, the deceased is intended magically taking possession of the cycle of creation and rebirth, an idea supported by the symbolism of these fish for recreation. (Hartwig 2004: 105).

A very important symbol in fowling scene is the hunted birds. The deceased use grey herons as decoys. The heron is a symbol rebirth of the rising sun and man's recreation after death. In general, birds were associated with the enemies of the Creator god; those birds must be destroyed to preserve the comic order. By killing birds with his throw stick, the deceased could maintain cosmic order by dispel the forces of 
chaos that could enter the tomb and break his family's eternal peace" (Hatwig2004: 104).

In the fishing and fowling scene in the tomb of Nakht, Nakht wife is dressed in a transparent dress that is tied around her breast, she also wears a broad collar and floral wreath over her wig. In this scene, the wife's dress presents her as an alluring symbol of sexuality. The goose on the boat's prow is of erotic associations and has a sacred connection to the god Amun-Re. The pintail ducks that are flying out from the papyrus thicket also carry sexual symbolism (Hartwig 2004, 105-106).

In the tomb of Menna, the fishing and fowling scene can be read both literally and symbolically. It represents recreation that occurred during Menna's life and could help him eternally in the afterlife. In the scene Menna is represented destroying chaos, represented by the wild birds, this prevents the evil spirits from entering the tomb to harm those who dwell in. These images are also erotically charged: the throw stick and the sensuous clothing of Henuttawy, and erotic place of the marsh dedicated for the goddess of love, Hathor, all the elements were gathered in the scene to ease the sexual union of Menna and his wife in the hereafter, which would lead to their eternal recreation (Hartwig 2013: 83).

\section{EgYPTOLOGY EDUCATION AND TRAINING FOR THE GUIDE}

It is noted that the growth and evolution of tourism, specially cultural tourism, and the different range of roles expected of and played by tour guides, raised the need for tour guides to gain knowledge and experience through training, education and professional development (Weiler and Black 2015a, 134). Effective tour guiding depends on a good education, continuous training and strong experiences, all these elements beside deep knowledge of the destinations, lead to a good interpretation of sites (İrigüler and Güler 2016, 204). Many authors acknowledge the multiple roles of the guide and note that the relevant skills and knowledge to perform these roles can be addressed through training and education (Black 2002; Black and Weiler 2005)

Professional associations and professional certification are the ways that supposed to achieve these goals. Professional associations can help in reaching the targeted knowledge for their students and they contribute to the professionalization of the industry in general, through applying ethical practices, continuing education, regular recertification or relicensing and monitoring of standards (Weiler and Black 2015a, 157).

Academic studied the interpretation qualities of tour guides in Egypt and other developing countries are dissimilar in evaluating the performance of 
the Egyptian tour guides concerning cultural heritage interpretation. Example of the negative mediation of understanding is McGrath's (2007) critique of tour guiding of archaeological sites in Peru., like Kohl (2007), suggests that the role of the guide in developing countries needs to be a facilitator and broker and not the traditional "show-and-tell" role currently assumed by guides in many of these countries (Weiler and Black 2015a, 38).

Although El Kilany in her study of the performance of Egyptian tour guides with UK Tourists, concluded that concerning knowledge most of the observed Egyptian tour guides were so informative and excellent in terms of ancient Egyptian civilization (E1 Kilany E 2010 , 9).

El-Sharkawy (2007) found a shortage among Egyptian tour guides to perform effectively, who, despite being licensed, lack the relevant education and knowledge. She studied the effect that this had on their recognition as a professional tour guide by the relevant tourism authority. She found that most Egyptian guides did their own research for their tours and learnt from other experienced guides, but they lacked formal knowledge and training and suggested that tour guiding courses should be delivered basically across well-known educational institutions (El Sharkawy 2007, 90).

The knowledge in general and specially Egyptology can subsidize the interpretation of the tour guide, especially the knowledge of Egyptology support the tour guide interpretation for archeological sites in Egypt. At an individual level, training can increase guides' knowledge of relevant academic topics, provide and enhance specific skills, and improve a guide's employment opportunities. This training of Egyptology encourages guides to solidify their skills and knowledge.

Providing a suitable education and training for tour guides is now of tourism policy priorities all over the world. Professional education and training is a must in higher institutions of tourism education where there is a tour guiding department (Huang and Weiler 2010; Yamada, 2011).

Professional certification is used in Egypt for tour guides to raise guiding standard and performance. The knowledge of Egyptology is a cornerstone in study in tour guiding departments. It is noted that certification establishes minimum standards needed for professional guide. Certification programs are based on general bases such as communication, leadership, and interpretation (Black 2013, 223).

The knowledge of Egyptology and training are the most important skills the Egyptian tour guide must have, in this context; the role of academic 
institutions in fundamental in delivering this knowledge to the future guides.

\section{CONCLUSION}

A link between guiding and the knowledge about the sites in which the guide works is an essential factor for the success of the tour. The interpretation of archeological sites is a neglected field of study in tour guiding literature. Interpretation in fact is crossed with other specialization than tour guiding, which is the study of the site itself. In Egypt; Egyptology is the study of archeological sites, a study that is the core of guides' in-site interpretation. Academics are entrusted in making solid relations between scientific theories and practice. This is the case in this research; it is a try to link the theories of Egyptology to practices of guiding in Egypt.

The right knowledge of some areas of specialization in Egyptology will change the guides' attitude and add professionalism to their work. Ancient Egyptian language and its use in guiding is a very important but neglected factor for the uniqueness of the tour guide. The example mentioned in the research of using a fundamental text from Luxor temple is suitable for illustrating the effect of the use of the ancient Egyptian language in guiding. The selected text shows the real function of Luxor temple, it is a new view opposite to the classic inaccurate ideas about the temple.

Other examples of how to apply Egyptological knowledge in guiding in sites in Luxor are discussed in other parts. The sacred lake of Karnak temple is a very important landmark in Luxor. Egyptology gives an accurate explanation about the function of the lake; a new but right academic view must be used in guiding to illustrate the right function of the place. Temples of millions of years and tombs of the nobles in western Luxor are important landmarks of the city; through Egyptological studies the guide can interpret these places in more suitable and right way.

It is the work of professional institutions to give the guide the suitable education and training, and the academics in tour guiding departments in Egypt are those who are entrusted with delivering such deep knowledge for the guides to use it in their interpretation of the sites.

\section{BIBLIOGRAPHY}

Ababneh, A. (2018): Tour guides and heritage interpretation: guides' interpretation of the past at the archaeological site of Jarash, Jordan, Journal of Heritage Tourism vol. 13, 13:3, 257- 
272.Available online at:http://dx.do i.org/10.108 0/1743873X .2017.1321003 (Last accessed 7/11/2020).

AL Rawadieh, Z. E. (2015) Tour Guiding and tourist groups conducting tools. Jordan University

Bell, L. D. 1998. The New Kingdom "divine temple": the example of Luxor. In B. E. Shafer (ed.), Temples of Ancient Egypt. London and New York: 127-84.

Black, R. 2002. Towards a model for tour guide certification: An analysis of the Australian ecoguide program. PhD Thesis, Monash University.

Black, R. and Weiler, B. 2005. Quality assurance and regulatory mechanisms in our guiding industry: A systematic review. Journal of tourism studies 16 (1). 24-37.

Black R. 2013. In pursuit of quality tour guiding: A review of tour guide quality assurance and regulatory mechanisms. 3rd International Research Forum on Guided Tours. Breda University of Applied Sciences, Netherlands.

Bryan B. M. 2001a. Temples of Millions of years in Western Thebes. In Weeks K. (ed.) Treasures of the valley of the kings Tombs and temples of The Theban west bank in Luxor. AUC. 54-59.

Cohen. E. 1972 Toward a Sociology of International Tourism. Social Research 39(2): 164- 182.

Cohen, Erik 1985: The Tourist Guide: The Origins, Structure and Dynamics of A Role, Annals of Tourism Research, Vol. 12, 5-29.

EL-Kilany, Engy 2010: Assessing the Intercultural Communication Performance of Egyptian Tourist Guides with UK Tourists, Journal of Association of Arab Universities for Tourism and Hospitality Vol.7, part 1.

El Sharkawy, O.K. (2007) Exploring knowledge and skills for tourist guides. Evidence from Egypt. Multydisciplinary Journal of Tourism 2 (2), 77-94.

Hartwig, M. K. 2004. Tomb Painting and Identity in Ancient Thebes, 1419-1372 BCE. Monumenta Aegyptiaca X. Brepols Publishers n.v., Turnhout, Belgium

Hartwig, M. K. 2013. The Tomb Chapel of menna (TT69). Cairo: American University in Cairo Press. 
Haeny, G. 1998. New Kingdom mortuary temples and mansions of millions of years, In Shafer, B. E. (ed.), Temples of Ancient Egypt, London.

Huang, S. and Weiler, B. (2010) a review and evaluation of China Assurance system for tour guiding. Journal of Sustainable Tourism 18 (7), 845-860.

İrigüler f. and Güler M. E. 2016: Tourist Guiding: "Cinderella" of the Tourism. In Avcikurt C. et al (eds.) Global Issues and Trends in Tourism. St. Kliment Ohrid ski University Press. 203-216.

Kohl, J. (2007) Putting the ecotour guide back into context: Using system thinking to develop quality guides. In R. black and A. Crabtree (eds) Quality Assurance and Certification in Ecotourism (pp. 337363) Oxford: CAB International.

Manniche L. 1987.City of the Dead. Thebes in Egypt. British museum.

Murnane W. J. 1999. Medinet Habu. In Bard K. A. (ed.) Encyclopedia of the Archaeology of Ancient Egypt, 578-583. New York.

Maccannell, D. (1976) The Tourist: A New Theory of the Leisure class. London: macmillan.

Mcgrath, G. (2007) Towards developing tour guides as interpreters of cultural heritage: The case of Cuso, peru. In R. black and A. Crabtree (eds) Quality Assurance and Certification in Ecotourism (pp. 364-394) Oxford: CAB International.

Murnane W. J. 1999. Medinet Habu. In Bard K. A. (ed.) Encyclopedia of the Archaeology of Ancient Egypt, 578-583. New York.

Nettekoven. L. 1979: Mechanisms of Intercultural Interaction. In Tourism: Passport to Development? E. de Kadt. ed. pp. 135- 145. New York: Oxford University Press

Shaw I. and Nicholson P. 2002. The British museum dictionary of Ancient Egypt. AUC.

Sotohy H. T. 2016. Reading Ancient Egypt, part one Thebes. Cairo

Strudwick, N. and Strudwick, H. 1999. Thebes in Egypt: A Guide to the Tombs and Temples of Ancient Luxor. Ithaca. Cornell University Press.UNESCO World heritage sites: www.unesco.org /whc/ sites/ 87.htm

UNWTO, 2001: United Nations World Tourism Organization. (2001). Tourism 2020 vision. Madrid: World Tourism Organization. 
Van der Merwe, C.D., 2016. Tourist guides' perceptions of cultural heritage tourism in South Africa. In: Szymańska, D. and Biegańska, J. editors, Bulletin of Geography. Socio-economic Series, No. 34, Toruń: Nicolaus Copernicus University, pp. 117130.

Weeks K. R., 2001. Thebes: A model for every city. In Weeks K. R., (ed.) The treasures of the valley of the kings, tombs and temples of the Theban west bank in Luxor. 22-33. Cairo.

Weeks K., R., 2005. The illustrated guide to Luxor tombs, temples and museums, Cairo.

Weiler, B., Black, R. (2015a). Tour Guiding Research, Insights, Issues and Implications. Aspects of Tourism 62. Bristol, UK: Channel View publications.

Weiler, B. \& Black, R. (2015b). The changing face of the tour guide: oneway communicator to choreographer to co-creator of the tourist experience, Tourism Recreation Research, 40:3, 364-378 available at:https://doi.org/10.1080/02508281.2015.1083742 (Last accessed 7/11/2020)

Yamada, N.(2011) Why tour guides is important in ecotourism: enhancing guiding quality with the ecoutourism promotion policy in Japan. Asia Pacific journal of TourismResearch 16 (2), 139-152.

Yenipinar U., 2016. Interpretation of Zeugma Museum by Tourist Guides. In Avcikurt C. et al (eds.) Global Issues and Trends in Tourism. St. Kliment Ohridski University Press. 73-86.

Zhang, H. Q., \& Chow, I. (2004). Application of importance-performance model in tour guides' performance: Evidence from mainland Chinese outbound visitors in Hong Kong. Tourism Management, 25(1), 81-91. 